\title{
Effects of non-invasive ventilatory support in tolerance to the effort of patients with hemodialysis
}

\author{
Suporte ventilatório não invasivo na tolerância \\ ao esforço de pacientes hemodialisados
}

\author{
Nathalie Cortez Bezerra de Medeiros ${ }^{[a]}$, Joelson dos Santos Silva ${ }^{[a]}$, \\ Nayara Priscila Dantas de Oliveira ${ }^{[a]}$, Ananília Regina Silva Cavalcante ${ }^{[a]}$, \\ Carolina Taveira Gonçalves ${ }^{[a]}$, Karla Luciana Magnani $\left.{ }^{[a, b}\right]^{*}$ \\ [a] Universidade Federal do Rio Grande do Norte, Faculdade de Ciências da Saúde do Trairi (FACISA/UFRN), Santa Cruz, RN, \\ Brazil \\ [b] Universidade Estadual Paulista (UNESP), São Paulo, SP, Brazil
}

\begin{abstract}
Introduction: The kidney system is responsible for the maintenance of homeostasis and in patients with Chronic Kidney Disease the kidney functions changes, contributing for the development of various complications that will have adverse effects in tolerance to the physical exercise and in Quality of Life of this patients. Objective: To evaluate the Effects of non-invasive ventilatory support in tolerance to the patients' physical exercise in dialysis. Methods: The patients performed two 6-minute walk tests, following an adapted protocol for treadmill, one of them without the use of non-invasive ventilatory support and the other with non-invasive ventilatory support during the walk. Besides, the patients answered a questionnaire of quality of life and the KDQOL-SF ${ }^{\mathrm{TM}}$ specific for the population under study. Results: It was noticed that there was not statistical difference in the distance recorded during the 6-minute walk tests. Regarding the quality of life, the greater impact of the disease was in relation to "Professional Activity". Conclusion: In conclusion, a non-invasive ventilatory support did not cause significant effects in tolerance to the exercise of this population. However, we should take into consideration the limitations suffered during the research development.
\end{abstract}

Keywords: Chronic Kidney Failure. Quality of Life. Tolerance to the Exercise.

\footnotetext{
NCBM: Master Student, e-mail: nathfisio9@gmail.com JSS: BS, e-mail: joelsonsantos_sc@hotmail.com NPDO: MS, e-mail: nayoliveira.fisio@gmail.com ARSC: BS, e-mail: ananiliaregina@gmail.com CTG: Master Student, e-mail: carolrtaveira@hotmail.com KLM: PhD, e-mail: klmagnani@gmil.com
} 
Resumo

Introdução: O sistema renal é responsável pela manutenção da homeostasia do corpo e, em pacientes com Doença Renal Crônica a função dos rins se altera, contribuindo para o desenvolvimento de várias complicações que influenciarão negativamente na tolerância ao exercício físico e na qualidade de vida destes pacientes. Objetivo: Avaliar os efeitos do uso da ventilação mecânica não invasiva na tolerância ao exercício físico de pacientes em tratamento dialítico. Métodos: Os pacientes realizaram dois testes de caminhada de seis minutos, seguindo um protocolo adaptado para esteira, sendo um teste sem o uso da ventilação não invasiva e outro teste com ventilação não invasiva durante a caminhada. Além disso, os pacientes responderam um questionário de qualidade de vida o KDQOL-SFTM específico para a população estudada. Resultados: Foi observado que não houve diferença estatística na distância percorrida durante os testes de caminhada em esteira. Em relação à qualidade de vida, o maior impacto da doença foi em relação à "Atividade Profissional". Conclusão: Em conclusão, a ventilação não invasiva, não causou efeitos significativos na tolerância ao exercício desta população, porém, devem-se levar em consideração as limitações sofridas durante o desenvolvimento da pesquisa.

Palavras-Chave: Falência Renal Crônica. Qualidade de Vida. Tolerância ao Exercício.

\section{Introduction}

The Chronic Kidney Disease (CKD) is determined by the loss of glomerular, tubular and endocrine function of kidneys in a progressive and irreversible way $(1,2)$. With its progression, kidneys become unable to maintain the normal functioning of body systems (1), requiring the treatment of renal replacement (3).

The number of patients on dialysis and served by SUS in the country has grown in the past few years, contributing to characterize this disease as a public health problem (4). According to 2011 Census from Brazilian Society of Nephrology (BSN), currently there are 91.314 Brazilians on dialysis per year, considering that $84.9 \%$ of services are carried out by SUS (5).

The kidney system is responsible for the maintenance of homeostasis, removing toxic substances and wastes, and for the hormone production. With its function changed by CKD, patients are more prone to systemic arterial hypertension, water retention, anemia (2) and musculoskeletal disorders (6), including the respiratory musculature (1). Patients may develop a generalized muscle weakness, affecting negatively on the tolerance to physical exercise and on the quality of life (QL) of patients $(1,6)$.

The functional capacity of these individuals is precarious, damaging both the performance of physical activities and the development of their daily life activities (7). One way to measure the functional status of patients is to perform a 6-minute walk test (6WT), in addition to providing information regarding cardiorespiratory responses to the exercise (8). This test can be performed on a treadmill (tread6WT) when there is no runner available or the necessity of a more specific monitoring of the patient (9).

The utilization of non-invasive ventilatory support (NIV) can improve tolerance to the exercise, as it improves the cardiorespiratory response during the exercise (10). The usage of this therapeutic modality is indicated in acute respiratory failure, chronic obstructive pulmonary disease (COPD), acute pulmonary edema, congestive heart failure (CHF) (11), among other situations. However, there are no studies regarding the usage of NIV in patients with CKD. In this sense, this study aims to estimate the usage effects of non-invasive ventilatory support in the tolerance to the effort in the treadmill 6-minute walk test of patients in dialysis. Furthermore, this study proposes an evaluation of pulmonary function and the quality of life in patients with CKD in dialysis.

\section{Methods}

Study description, population and sample

An almost experimental study was made at the Clinical School of Physiotherapy from College of Health Sciences of Trairi of the Federal University of Rio Grande do Norte (FACISA/UFRN), with initial sample of 21 individuals with CKD in dialysis, registered at the Health Department of the city of Santa Cruz/RN and residents. This was a non-probability sampling, defined by the accessibility to the individual. This almost experimental protocol was submitted and approved by Ethics 
Committee in Research from the Federal University of Rio Grande do Norte, under the number 249.874/2013, following the guidelines of the Resolution 196/96, from the National Health Council.

Inclusion criteria were established: individuals of both sexes, with diagnosis of CKD, in dialysis and with medical permission for executing the research protocol provided by the cardiologist participant in the research. Patients with cognitive impairment, presenting any kind of limitation (orthopedic, musculoskeletal, rheumatologic, cardiopulmonary or neurological) that could prevent tests accomplishment, and other clinical conditions that could be exacerbated by physical effort were excluded from the sample.

\section{Procedure for data collection}

Initially, all patients signed an Informed Consent Document (ICD), attesting to be aware and in agreement of procedures performed during the study. Moreover, individuals underwent a cardiac evaluation, so that they could be released to perform tests suggested in the protocol.

The research occurred in three distinct phases, performed every other day. The first phase is the execution of an assessment (anamnesis and physical exam) and pulmonary function tests (spirometry and manovacuometry). The other two phases consisted in the execution of a tread6WT in two distinct situations, following the protocol suggested by Camargo et al. (9). The initial speed was $2 \mathrm{~km} / \mathrm{h}$, and may be increased by $1 \mathrm{~km} / \mathrm{h}$ every 30 seconds, depending on the patient tolerance, reaching a maximum of $8 \mathrm{~km} / \mathrm{h}$, or if requested to be reduced, this would be done in $0,5 \mathrm{~km} / \mathrm{h}$ in every request. Tests in a treadmill was performed without inclination. In order to obtain the value of the forecasted traveled distance for each patient, a formula proposed by Iwama et al. (12) was used. Phases were executed always at the same time and the room temperature was kept always in $26^{\circ} \mathrm{C}$.

Pulmonary function tests were obtained through the device Koko Legend Spirometer 314000 - Nspire, following the recommendations of Pereira (13) and Silva et al. (14). Predicted values were calculated according to the reference of normality established by Pereira et al. (15).

Maximum inspiratory and expiratory pressures (maxIP and maxEP) were measured through the digital manovacuometer Globalmed ${ }^{\circledR}$ MVD300, adopting the protocol suggested by Souza (16). References of normality, measurement of values and the choice of the best curves respected the description of the method proposed by Neder et al. (17).

\section{Experimental protocol}

After performed the initial evaluation, patients underwent two tread6WT. Tests occurred in every other day and their order was drawn for each patient. Each test occurred as follows:

Test 1 (tread6WT without NIV): Initially, the following were measured: systemic arterial pressure (AP) at rest, peripheral heart rate (HR) at rest, respiratory rate (R) at rest, oxygen peripheral saturation (02Ps) at rest and the sensation of effort through the noticed effort scale of BORG (18). Afterwards, a tread6WT was accomplished. During the test, parameters AP, HR, R and 02Ps and Borg were monitored. In the second, fourth and sixth minutes. After five minutes from the end of the tread6WT, the same variables were measured again, in order to verify the return of vital signs to pre-test values.

Test 2 (NIV during the tread6WT): This phase was similar to phase 1 - the only modification was the use of NIV by positive pressure of two levels (bilevel) during the tread6WT.

The AP at rest, during and at the end of tests was measured indirectly through the aneroid sphygmomanometer and Premium ${ }^{\circledR}$ stethoscope. The HR and 02Ps at rest, during and after the test, were measured using a digital pulse oximeter Solmedica ${ }^{\circledR}$ MD300C1. An evaluator measured the $\mathrm{R}$ during the Test 1 , with the hand placed next to the nose of the individual and, during the Test 2 that was obtained through the device of NIV.

The device used to generate the non-invasive ventilatory support was the BIPAP ${ }^{\circledR}$ Synchrony II Respironics. The inspiratory positive airway pressure (IPAP) was the minimum that guaranteed the patient a tidal volume of $8-10 \mathrm{ml} / \mathrm{Kg}$; the expiatory positive airway pressure (EPAP) was the minimum that guaranteed an 02Ps of $90-92 \%$.

\section{Analysis of Quality of Life}

In order to evaluate the QL of patients, the Kidney Disease and Quality-of-Life Short-Form (KDQOL$\mathrm{SF}^{\mathrm{TM}} 1.3$ ) was used, which is a specific tool that evaluates individuals with CKD, applicable to patients undergoing some kind of dialysis program. By including issues related to generic and specific aspects of the kidney disease, it can be considered the most complete questionnaire available nowadays to evaluate the QL of patients with 
CKD. Thr KDQOL-SF ${ }^{\mathrm{TM}}$ consists of 80 items, divided into 19 dimensions and, includes the SF-36 more 45 items related to CKD (19).

The score of each item of this tool varies from zero to 100 , with the higher values as a reflection of a better QL (20).

\section{Statistical Analysis}

Obtained data were analyzed through descriptive and inferential statistic, using the SPSS v. 20 for Windows as a program. The statistic relevance will be considered for $p$-with a value of less than or equal to 0,05 . A generalized estimating equation (GEE) was performed.

\section{Results}

Six patients with CKD in dialysis composed the final sample of this study. The majority were women $(66.67 \%)$ and the age average was 47.2 years-old $( \pm$ 14.9). Fifteen individuals did not participate in the research because they were framed in some of the exclusion criteria, refusal or death (Table 1). All patients were treated by hemodialysis and the average time of dialysis, in months, was 44.5 ( \pm 51.3$)$.

Table 1 - General Characteristics of the Sample Studied

\begin{tabular}{|c|c|c|c|}
\hline \multicolumn{2}{|c|}{ Characteristics } & $\mathbf{n}$ & $\%$ \\
\hline \multicolumn{4}{|c|}{ Sample } \\
\hline \multicolumn{2}{|c|}{ Initial Sample } & 21 & 100 \\
\hline \multicolumn{2}{|c|}{ Final Sample } & 6 & 28.57 \\
\hline \multirow[t]{2}{*}{ Sex } & Men & 2 & 33.33 \\
\hline & Women & 4 & 66.67 \\
\hline \multicolumn{4}{|c|}{ Reasons of the sample loss } \\
\hline \multicolumn{2}{|l|}{ Death } & 1 & 6.67 \\
\hline \multicolumn{2}{|c|}{ Refusal } & 8 & 53.34 \\
\hline \multicolumn{2}{|c|}{ Physical Limitation } & 5 & 33.34 \\
\hline \multicolumn{2}{|c|}{ Other (Severe Anemia) } & 1 & 6.67 \\
\hline
\end{tabular}

The variables of spirometry, maxIP and maxEP were analyzed using descriptive statistic in order to characterize the pulmonary function of the sample and the results are shown in Table 2.
Table 2 - Sample Characterization according to Pulmonary Function

\begin{tabular}{llc}
\hline Pulmonary Function & $\mathbf{n}$ & $\%$ \\
\hline Spirometry & & \\
Restrictive Ventilatory Disorder & 3 & 60 \\
Normal Spirometry & 2 & 40 \\
Respiratory Muscle Strength & & \\
maxIP & & \\
Normal & 2 & 33.33 \\
Reduced & 4 & 66.67 \\
maxEP & & \\
Normal & 4 & 66.67 \\
Reduced & 2 & 33.33 \\
\hline
\end{tabular}

Note: maxIP (Maximum Inspiratory Pressure ); maxEP (Maximum Expiratory Pressure).

The distance traveled in the tread6WT had an average of $407.5 \mathrm{~m}( \pm 115.68 \mathrm{~m})$, however, but none of the patients in this study were able to reach the individual expected distance for the tread6WT. There was no significant statistic difference between distances traveled and in the tread6WT without NIV and with NIV, as described in Table 3.

Table 3 - Distance traveled in tread6WT and comparative analysis of both tests

\begin{tabular}{|c|c|c|c|c|c|}
\hline Treatment & Average & Estimative & $\begin{array}{c}\text { Standard } \\
\text { Error }\end{array}$ & $p$-value & CI $95 \%$ \\
\hline $\begin{array}{l}\text { Without } \\
\text { NIV x } \\
\text { With NIV }\end{array}$ & - & -28.0608 & 14.86753 & 0.118 & - \\
\hline Tread6WT & & & & & \\
\hline $\begin{array}{l}\text { Without } \\
\text { NIV }\end{array}$ & 390.5125 & - & 6.45413 & - & $\begin{array}{c}378.0653 \\
: \\
403.3694\end{array}$ \\
\hline With NIV & 362.4517 & - & 8.46944 & - & $\begin{array}{c}346.2263 \\
: \\
379.4375\end{array}$ \\
\hline
\end{tabular}

Note: $p$-value $=0,05 ; \mathrm{Cl}$ (Confidence Interval).

Regarding the evaluation of the $\mathrm{QL}$, all the patients answered the KDQOL- SF ${ }^{\mathrm{TM}}$ questionnaire. The highest scores were obtained for dimensions related to the "Quality of Social Interaction", "Social Support" and "Social Function", while the lowest scores were "Professional Activity". All the patients' results are shown in Table 4. 
The IPAP of each patient was the minimum to guarantee a tidal volume (TV) of $8-10 \mathrm{ml} / \mathrm{kg}$, the average of pressures used in this sample was $8 \mathrm{cmH} 20$. The EPAP of each individual was to guarantee a SpO2 of 90-92\%, the average of pressures used in this study was $4 \mathrm{cmH} 2 \mathrm{O}$.

Tabela 4 - Descriptive Evaluation of Quality of Life of the sample studied

\begin{tabular}{|c|c|c|c|c|}
\hline Dimensions & Minimum & Maximum & Average & Variation \\
\hline \multicolumn{5}{|l|}{ ESRD } \\
\hline $\begin{array}{l}\text { Symptoms/ } \\
\text { Problems }\end{array}$ & 64.6 & 100 & 87.5 & $0-100$ \\
\hline $\begin{array}{c}\text { Effects of Kidney } \\
\text { Disease in Daily } \\
\text { Life }\end{array}$ & 31 & 81.25 & 64 & $0-100$ \\
\hline $\begin{array}{l}\text { Weight of Kidney } \\
\text { Disease }\end{array}$ & 31 & 68.75 & 49.9375 & $0-100$ \\
\hline $\begin{array}{l}\text { Professional } \\
\text { Activity }\end{array}$ & 0 & 0 & 0 & $0-100$ \\
\hline Cognitive Function & 73.30 & 100 & 86.6575 & $0-100$ \\
\hline $\begin{array}{l}\text { Quality of Social } \\
\text { Interaction }\end{array}$ & 86.66 & 100 & 94.9975 & $0-100$ \\
\hline Sexual Function & 0 & 100 & 59.375 & $0-100$ \\
\hline Sleep & 58 & 73 & 67.07 & $0-100$ \\
\hline Social Support & 66.66 & 100 & 91.665 & $0-100$ \\
\hline $\begin{array}{l}\text { Encouraging of } \\
\text { Dialysis Staff }\end{array}$ & 75 & 100 & 87.5 & $0-100$ \\
\hline Patient Satisfaction & 33.2 & 83 & 44.27 & $0-100$ \\
\hline \multicolumn{5}{|l|}{ SF-36 } \\
\hline Physical Function & 20 & 90 & 55 & $0-100$ \\
\hline $\begin{array}{c}\text { Physical } \\
\text { Performance }\end{array}$ & 0 & 100 & 56.25 & $0-100$ \\
\hline Pain & 50 & 100 & 76.875 & $0-100$ \\
\hline Health & 45 & 65 & 51.25 & $0-100$ \\
\hline Emotional Function & 40 & 96 & 69 & $0-100$ \\
\hline $\begin{array}{l}\text { Emotional } \\
\text { Performance }\end{array}$ & 66.66 & 100 & 74.995 & $0-100$ \\
\hline Social Function & 75 & 100 & 93.75 & $0-100$ \\
\hline Vitality & 50 & 90 & 72.5 & $0-100$ \\
\hline
\end{tabular}

Note: ESRD (Scales Related to Kidney Disease); SF-36 (Short Form Health Survey).

\section{Discussion}

During this study, a treadmill walk test protocol was adopted, proposed by Camargo et al. (9). An ergometer was used to perform the test because the NIV device available was not portable, making impossible to perform a conventional walk test.

Patients with CKD develop changes in several body systems, characterizing the uremic syndrome. Among these changes, we can find atrophy and weakness of skeletal muscles, which are clinical manifestations of uremic myopathy. The muscles responsible for breathing may have their strength and resistance decreased during the myopathy, once these muscles are classified as skeletal (1, 20 - 23).

In this study, it was verified that maxIP was reduced in most of the sample (66.67\%). It was also observed that maxEP was reduced in a part of the sample (33.33\%). These results are similar to those found by Cury et al. (1), which compared the maxIP and maxEP among dialyzed patients (DG), transplanted (TG) and one control group (CG). When the DG was compared with the $\mathrm{CG}$, it was observed a reduction in both maxIP and maxEP. When comparing the DG with the CG, it was observed a reduction in both maxIP and maxEP. When comparing DG with the TG, the maxIP of the DG also presented a reduction, and compared with the $\mathrm{CG}$, the TG presented a disposition for low maxIP and maxEP. Dipp et al. (23), evaluated 30 individuals and found a reduction in maxEP of $14.2 \%$ in relation to predicted values. However, the maxIP presented no statistical difference. In the study of Kovelis (24), it was analyzed 17 patients with CKD and authors observed no significant alteration in maxIP and maxEP, which is different from the findings of this study.

This change of strength regarding musculature affects the function of the respiratory system and contributes to the reduction of pulmonary capacity (1). Besides, the deficient pulmonary function of these patients can be a direct result of the increase of uremic toxins circulation, or can be indirectly affected by the volume overload, anemia, immunosuppression, heterotopic calcification, malnutrition, electrolytic disorders and acid-basic unbalance (25).

Regarding the pulmonary function, it was found that $60 \%$ of the sample presented a degree of restrictive ventilatory disorder (RVD). Corroborating with these findings, Faria et al. (21), as performing a forced spirometry, observed that 2 patients presented a mild RVD and 4 patients presented a mixed ventilatory disorder 
(MVD). Cury et al. (1) showed that in the group of individuals undergoing dialysis, 1 individual presented a MVD and 7 were classified as presenting a RVD, in the group of transplanted only 1 individual presented a RVD and the sample remaining presented no alteration in the spirometry.

The dialysis routine of patients with CKD has impact in the QL, mainly harming physical capacity and performance of daily activities, increasing sedentary habits and thus increasing the risk of mortality $(23,25)$.

In this study, best results in the QL questionnaire were observed in the field of "Quality of Social Interaction", "Social Support" and "Social Function". Similar to the findings of this research, the results found by Coutinho et al. (26) and Fahur et al. (27). Schardong et al. (20), through the analysis of QL from patients with CKD, found that the worst scores in the KDQOL-SF ${ }^{\mathrm{TM}}$ questionnaire were seen in the field of "Overload of Kidney Disease" and "Professional Role", which supports the findings of this research that, in his evaluation, found that the field with lower score in the same questionnaire was to "Professional Role". Some studies describe this same result regarding "Professional Role" (26 - 28).

The reduction of functional capacity is related to a number of factors such as cardiopulmonary and musculoskeletal changes, among others. These factors characterized the uremic syndrome and leads to dyspnea, fatigue, anemia, muscular weakness among other alterations $(23,25)$.

When evaluated the functional capacity of patients with CKD through the tread6WT, it was observed that none of them reached the expected value of the individual distance traveled. Lima et al. (29), evaluated patients with CKD before and after the program during the tread6WT. Regarding their functional capacity, it was observed that values obtained in the 6WT were significantly lower than the predicted values for this population. Cury et al. (1) observed that there is a tendency for individuals with CKD to obtain lower results in comparing the expected with the general population. Faria et al (21) noticed that only one individual from the sample, after the 6WT, presented a lower result than the expected in the walk test, and the other patients achieved the expected values.

When evaluated the effect of the use of NIV in the tolerance to the effort in the tread6WT, it was observed no significant difference in the tolerance to the effort of patients during the tread6WT with or without NIV. However, studies with other populations that performed the $6 \mathrm{WT}$, showed that the use of this therapeutic modality improves the performance of patients, as shown by Lima et al. (29), in a sample of patients with CHF, the use of NIV through the CPAP increased the distance traveled in the 6WT when compared to the control group that made no use of NIV. Costa et al. (30) studied the use of NIV through the do Bipap ${ }^{\circledR}$ in patients with COPD and observed an increase in the distance traveled in the 6WT after the use of this therapeutic modality.

\section{Conclusion}

It can be observed that patients with CKD present pulmonary disorders and reduction of their QL. Alterations in the pulmonary system of patients in this sample were discreet, but contribute directly for the reduction of their functional capacity, as well as the low QL presented by them.

The use of NIV through the Bipap ${ }^{\circledR}$ during the tread6WT cased no significant effects in the tolerance to the physical exercise of patients with CKD. Some study limitations may have contributed to these results: reduced sample size, patients' familiarity with the ergometer used and clinical profile (insignificant cardiorespiratory limitations). Furthermore, this was the first study regarding effects of NIV in tolerance to the exercise in patients with CKD.

In this sense, it is suggested to perform other studies with larger samples, and composed by patients with different compromising levels of functional capacity, in order to investigate the effects of NIV in patients with CKD, and to observe there is any impact in pulmonary function and QL of individuals.

\section{References}

1. Cury JL, Brunetto AF, Aydos RD. Efeitos negativos da insuficiência renal crônica sobre a função pulmonar e a capacidade funcional. Braz J Phys Ther. 2010;14(2):91-8.

2. Morsch C, Veronese FJV. Doença renal crônica: definição e complicações. Rev HCPA. 2011;31(1):114-5.

3. National Kidney Foundation. Sobre Insuficiência Renal Crônica. Guia para Pacientes e Familiares. 2008 [cited 2012 Sep 23]. Available from: http://tinyurl. com/hmx8env. 
4. Pezzini CA, Zanata J, Maraschin R, Mortari DM, Scapini K, Leguisamo CP. Repercussão da hemodiálise na função pulmonar e força muscular ventilatória em pacientes com doença renal crônica terminal. Fisioter Bras. 2012;13(2):112-7.

5. Sociedade Brasileira de Nefrologia. Censo de diálise SBN 2011 [cited 2012 Sep 19]. Available from: http:// tinyurl.com/zjwrx3g.

6. Marchesan M, Krug RR, Moreira PR, Krug MR. Efeitos do treinamento de força muscular respiratória na capacidade funcional de pacientes com insuficiência renal crônica. Revista Digital (Buenos Aires). 2008 [cited 2012 Sep 21]. Available from: http://tinyurl. com/jtrvrrj.

7. Medeiros RH, Pinent CEC, Meyer F. Aptidão física de indivíduo com doença renal crônica. J Bras Nefrol. 2002;24(2):81-7.

8. American Thoracic Society. ATS Statement: Guidelines for the Six-Minute Walk Test. Am J Respir Crit Care Med. 2002;166(1):111-7.

9. Camargo VM, Martins BCS, Jardim C, Fernandes CJC, Hovnanian A, Souza R. Validação de um protocolo para o teste de caminhada de seis minutos em esteira para avaliação de pacientes com hipertensão arterial pulmonar. J Bras Pneumol. 2009;35(5):423-30.

10. Lima ES, Cruz CG, Santos FC, Gomes-Neto M, Bittencourt HS, Reis FJFB, et al. Suporte Ventilatório na Capacidade Funcional de Pacientes com Insuficiência Cardíaca: Estudo Piloto. Arq Bras Cardiol. 2011;96(3):227-32.

11. Ferreira HC, Santos FB. Aspectos gerais da Ventilação não-invasiva. Revista Científica do HCE. 2008;(2):73-81.

12. Iwana AM, Andrade GN, Shima P, Tanni SE, Godoy I, Dourado VZ. The six-minute walk test and body weight-walk distance product in healthy Brazilian subjects. Braz J Med Biol Res. 2009; 42: 1080-5.

13. Pereira CAC. Espirometria. J Pneumol. 2002;28(Supl 3):S1-S82.

14. Silva LCC, Rubin AS, Silva LMC, Fernandes JC. Espirometria na prática médica. Rev AMRIGS. 2005;49(3):183-94.

15. Pereira CAC, Sato T, Rodrigues SC. Novos valores de referência para espirometria forçada em adultos brancos no Brasil. J Bras Pneumol. 2007;33(4):397-406.
16. Souza RB. Pressões respiratórias estáticas máximas. J Pneumol. 2002;28(Supl 3):S155-S165.

17. Neder JA, Andreoni S, Lerario MC, Nery LE. Reference values for lung function tests. II. Maximal respiratory pressures and voluntary ventilation. Braz J Med Biol Res. 1999;32(6):719-27.

18. Coelho CC, Aquino ES, Lara KL, Peres TM, Barja PR, Lima EM. Consequences of chronic renal insufficiency on the exercise capacity, nutritional status, pulmonary function and respiratory musculature of children and adolescents. Braz J Phys Ther. 2008;12(1):1-6.

19. Duarte OS, Miyazaki MCOS, Ciconelli RM, Sesso R. Tradução e adaptação cultural do instrumento de avaliação de qualidade de vida para pacientes renais crônicos (KDQOL-SF ${ }^{\mathrm{TM}}$ ). Rev Assoc Med Bras. 2003;49(4):375-81.

20. Schardong TJ, Lukrafka JL Garcia VD. Avaliação da função pulmonar e da qualidade de vida em pacientes com doença renal crônica submetidos à hemodiálise. J Bras Nefrol. 2008;30(1):40-7.

21. Faria RS, Silva VSA, Reboredo MM, Fernandes NMS, Bastos MG, Cabral LF. Avaliação da função respiratória, capacidade física e qualidade de vida de pacientes com doença renal crônica pré-dialítica. J Bras Nefrol. 2008;30(4):264-71.

22. Bianchi PDA, Barreto SSM, Thomé FS, Klein AB. Repercussão da hemodiálise na função pulmonar de pacientes com doença renal crônica terminal. J Bras Nefrol. 2009;31(1):25-31.

23. Dipp T, Silva AMV, Signori LU, Strimban TM, Nicolodi G, Scruzzi G, et al. Força muscular respiratória e capacidade funcional na insuficiência renal terminal. Rev Bras Med Esporte. 2010;16(4):246-9.

24. Kovelis D, Pitta F, Probst VS, Peres CPA, Delfino VDA, Mocelin AJ et al. Função pulmonar e força muscular respiratória em pacientes com doença renal crônica submetidos à hemodiálise. J Bras Pneumol. 2008; 34(11):907-12.

25. Jatobá JPC, Amaro WF, Andrade APA, Cardoso FPF, Monteiro AMH, Oliveira MAM. Avaliação da função pulmonar, força muscular respiratória e teste de caminhada de seis minutos em pacientes portadores de doença renal crônica em hemodiálise. J Bras Nefrol. 2008;30(4):280-7. 
26. Coutinho NPS, Vasconcelos GM, Lopes MLH, Wadie, WCA, Tavares MCH. Qualidade de vida de pacientes renais crônicos em hemodiálise. Rev Pesqui Saude. 2010;11(1):13-7.

27. Fahur BS, Yen LS, Ferrari GNB, Padulla SAT, Miranda, RCV. Avaliação da qualidade de vida com instrumento KDQOL-SF em pacientes que realizam hemodiálise. Qolloquium Vitae. 2010;2(2):17-21.

28. Oliveira MP, Kusumota L, Marques S, Ribeiro RCHM, Rodrigues RAP, Haas VJ. Trabalho e qualidade de vida relacionada à saúde de pacientes em diálise peritoneal. Acta Paul Enferm. 2012;25(3):352-7.

29. Lima FF, Miranda RCV, Silva RCR, Monteiro HL, Yen LS, Fahur BS, et al. Avaliação funcional pré e pós-programa de exercício físico de pacientes em hemodiálise. Medicina (Ribeirão Preto). 2013;46(1):25-34.

30. Costa D, Toledo A, Borghi-Silva A, Sampaio LMM. Influência da ventilação não invasiva por meio do Bipap $^{\circledR}$ sobre a tolerância ao exercício físico e força muscular respiratória em pacientes com doença pulmonar obstrutiva crônica (DPOC). Rev Latino-Am Enferm. 2006;14(3):378-82.

Received in 09/01/2014

Recebido em 01/09/2014

Approved in 05/16/2016

Aprovado em 16/05/2016 